\title{
Banks Responses to Deregulation: Revenues, Costs and Profits-Evidence from Jordan
}

\author{
MOHAMMAD I. AL-ABADI \\ KHALED A. AL-ZOUBI \\ HUSNI A. KHRAWISH \\ Assistant Professors \\ Department of Banking \& Finance \\ College of Economics and Administrative Sciences \\ The Hashemite University, Zarqa, Jordan
}

( Received 01.08.1423H, and Accepted 14.02.1424H )

\begin{abstract}
The main interest of this paper is to outline the major responses of banks toward deregulation and financial reforms. Thus, it examines the impact of the regulatory reform on banking efficiency performance. This was achieved by examining the effects of deregulation and banking reforms on revenues, costs and profits efficiencies given input and output prices. The examination was extended to investigate whether the regulatory reform creates structural changes in the banks' investing and financing behavior. While, the results show no substantial increase in banks profits, the overall indication specifies that most of the measure controls adopted by the CBJ improved the soundness of the banking sector in Jordan. The analysis reveals an increase in costs which attributed to change in the market conditions, in addition to the increase in the structural costs caused by the deregulation and the reform regimes. The low profit levels is attributed to increased competition that forced banks to follow a restricted behavioral policy of not widening their spreads, and focus on achieving stable interest rate margins instead. The results revealed that, because of increased competition, banks increased their relative dependence on the interbank funding, in addition to increase their access toward the deposit market. The results indicated also more reliance on using capital reserve.
\end{abstract}

\section{Introduction}

Broadly, examining efficiency performance determinants in the banking industry has public policy implications. This seems to be very obvious under the fact that regulatory bodies normally search to achieve more competitive and efficient financial system, causing the need for fundamental movements toward deregulation and financial reforms. This movement was crucial due to numerous factors that, in cumulative and progressive fashion, have produced the trend toward such attitude i.e., the government and the related financial enterprises concern toward developing the functioning of the nation's financial enterprises, the technological innovations, the public and consumer pressures (consumers need), and finally the changing economic and market conditions. 
In Jordan, during the last three decades in particular, most financial and non financial institutions were developed. Prior to deregulation and financial reform regimes, a comprehensive regulatory structure was imposed on the Jordanian banking industry following the economic and banking problems during the second half of 1980s. Up to the late 1980s, the focus of regulation was on the tight control of banks, which dominated the Jordanian Financial System (JFS). By the late 1980s and early 1990s, there was an increasing recognition that direct regulation of the financial institutions was not achieving its aims. Consequently, keeping the banking crises in mind, a movement toward deregulation and reforms began in an effort to provide an opportunity for a more competitive financial system. Since then, the government of Jordan has undertook several strategic controls i.e., removed price controls, eased investment restrictions, changed tax neutrality across different types of firms, exposed the local market to more international competition, and lowered the market entry and exit barriers.

Nevertheless, despite the importance of efficiency studies, the literature of performance efficiency in the Jordanian banking industry is limited. Therefore, a study of such area will be interesting to various groups, particularly regulators, consumer organizations and banks as well. However in order to outline the main responses of banks toward deregulation and financial reform regimes, this study examine whether the regimes led to an improvement in the overall banks performance efficiency. The examination is extended to investigate whether the regimes create structural changes of the banks investing and financing behavior. All are fulfilled by evaluating the effects of the regimes on the revenue, cost and profitability efficiencies in the banking industry. One of the motivations behind the need to search this topic is to examine if there is still a room for the Jordanian banking industry to become more efficient, and to find out if size alone determines levels of efficiency, reflecting the opportunity to identify which other factors determine efficiency. The second motivation, in addition to provide banks with some strategic planning, is to provide the regulatory bodies with suggestions that may create an appropriate regulatory environment.

The remaining parts of this paper are structured as follows. In part 2, the paper provides an overview of the literature, while part 3 investigates the forces behind deregulation and financial reforms in the Jordanian Banking Industry (JBI), and outlines the evolution of the new banking measure controls adopted by the Central Bank of Jordan (CBJ) during the late 1980s and 1990s. Part 4 defines the estimation specification procedures, in which the period and data sample is given, the proxies and initial tests are specified. In part 5, the functional estimation results are presented, while in part 6 we conclude the empirical tests with a summary of the results and their implications.

\section{Literature Review}

In general terms, over the last few decades, the movement toward deregulation and financial reform regimes were adopted as a basic strategy to meet most challenging conditions facing financial systems in general, and the banking industry in particular. This movement includes most industrialized, developing and transition countries. The new regimes focused on the liberalization on interest rates, removing the quantitative controls on lending activities, lifting barriers to competition, privatization of public enterprises, in addition to introducing market-based securities. Most, if not all, of these regimes aimed to increase the level of investment and the efficiency of its allocation, in addition to improving the provision of financial services to all economy sectors. 
Recently, evaluating the effects of deregulation and financial regimes on the performance of different financial sectors has received more care in the literature. Hardy and Bonaccorsi (2001) pointed out the two main approaches that exist in order to evaluate the effects of the financial markets reforms. The first of which, focuses on macro-economic variables that are closely related to the ultimate targets of the reform process i.e., savings and investment rates, real growth rates in the economy, and interest rates movements. Under this consideration, the first approach attempts to examine the behavioral changes in the macro-economic variables induced by the financial deregulation regimes. See, Johnston and Ceyla (1995), Demetriades and Kul (1996), Jbili et al (1997), Humphrey and Pulley (1997), Vivas (1997 and 1998), Gilbert and Wilson $(1998)^{(1)}$.

The second alternative approach is based on an individual analysis of each particular financial sector separately. This approach includes assessing the changes in the structure and performance of the sector under consideration following the reform process. For this approach, studies might attempt to estimate and examine the effects of some variables i.e., the cost efficiency, revenue efficiency, and profitability of the financial firms operating in one country, which are subject to the same regulatory environmental conditions and other disturbances. This approach is adopted in this paper following other similar studies that covered the experience with bank reform in Pakistan, the United States, China, Korea, Ecuador and Spain. See, Elyasyiani and Mehdian (1995), Bhattacharyya et al (1997), Berger and Master (1997), Sathye (1999), Berger et al (1993), Grabowski et al (1994), Lozano (1998), Kumbhakar et al (2001), Martinez (2001), Stiroh and Strahan (2002), Lee et al (2000), and Shirai and Rajasekaran (2001). Other studies focus on banks' efficiency by investigating the banks' profitability and performance e.g., Berger et al (1996), Berger (1993), Nickell (1996), Hunter and Timme (1993), Berger and Humphrey (1997), and Berger et al (1993).

\section{Major Banking Controls Adopted by the CBJ- Historical View}

Under market forces, and similar to other countries, Jordan adopted major financial section reforms, particularly in the banking industry. These reforms were achieved by moving from the regulatory regime to deregulation. In the late 1980s, particularly in August 1989, the Jordanian banking industry faced the emergence of major banking crises which were represented by the collapse of one major domestic commercial bank, Petra Bank, the third largest financial enterprise in Jordan, in addition to the major financial difficulties faced by Jordan Gulf Bank. These crises were a side with the emergence of financial difficulties in six other financial enterprises. All such events jeopardized the integrity of the Jordanian's banking system. However, Chauffour (1996) identified that the crises emerged due to three main factors: (1) inadequate banking regulations, (2) overexposure of the banking system to the real estate market, together with loan collateralized with real estate properties, and (3) Imprudent speculation on foreign exchange.

(1) Hardy and Bonaccorsi (2001) argue that the main deficiency of the first approach lies in the difficulty in isolating the effects of the financial deregulation from those of other institutional or macroeconomic developments. The difficulty increased for comparison purposes due to the possibility of lack of observation available for each country, in addition to the heterogeneity of experience and financial environment across different countries. 
The first factor represents two main weaknesses that the monetary bodies failed to detect within the regulatory framework, causing a widespread fraudulence in surveillance and management. The first weakness is typified by the lack of relevant banking supervision and prudential regulation practiced by the Central Bank (CB) toward banks, which are oriented toward long-term sectoral projects, creating the involvement to be exposed to risky financial intermediation. The surveillance role was limited to ensuring that banks are complying with some critical operating ratios and make sure of the credit limits without forcing banks to have proper risk credit analysis in their loan allocations. The second weakness is the lack of efficient regulatory accounting treatments toward loan loss provisions, particularly in identifying the nonperforming loans. The second main factor is represented by the large difficulties and non-performing loans in the banks' balance sheets. This was due to the real estate slump in the late 1980s, in addition to the oil shock that caused large inflows of workers' remittance. The third factor represents the bank's excessive exposure on their foreign exchange position. Several elements contributed to this factor particularly the weaknesses in the balance sheet payment position, the emergence of a parallel market for foreign exchange used mainly for speculative transactions in the form of positions between the official and the parallel market, in addition to the high level of foreign obligations that were over exposed by banks and other financial enterprises.

In order to face the above issues, the Central Bank undertook major monetary and banking controls and issued several additional regulatory correction measures. The objective was to improve the surveillance process, and to enhance the soundness and increase trust in the overall banking industry. Basically, the measures included instructions to govern loan loss provisions, capital requirement, and portfolio management.

Historically, during the period between 1989 and 2001 the CBJ adopted the following instructions. As an example, by the year 1989, in order to augment the foreign exchange reserves of the $\mathrm{CB}$ and to provide an additional protection to holders of deposits in foreign currencies, all licensed banks and financial companies were instructed to deposit $35 \%$ of their total deposits as a required reserve with the CB. These deposits were in the form of a deposit carrying interest similar to those prevailing in the international market. Regarding the foreign currency deposits of residents, the CBJ got rid of the constraint of tying them for a specific period of time, six months for example. This makes such deposits to be more readily available to meet the foreign exchange commitments of holders. On the other hand, the CBJ specified the sources of foreign currencies that the bank clients must provide for financing their imports into the free zones as being clients deposits in foreign currencies, documentary credits, incoming transfers received on their behalf and foreign banknotes.

In the early 1990, the CBJ liberalized the interest rates charged by banks and financial companies on different types of banks' facilities. To encourage local investment, the CBJ instructed licensed banks to increase their minimum investment in public shares from $15 \%$ to $20 \%$ of total paid up capital and reserves. Foreign exchange control regulations were also subject to certain modifications introduced by the CB by the late 1990. These modifications included increasing the ceiling of foreign currency deposits held by residents with banks and other financial companies in the country to the equivalent of JD 150,000 instead of JD 50,000. Other modifications were introduced 
to foreign currency control regulations limiting deposits by exporters with local banks to only $10 \%$ instead of $30 \%$. This was due to the significant improvement in the foreign exchange position of the banking system which became able to finance raw material imports. To preserve the financial soundness of investment banks and to safeguard the rights of shareholders and depositors, the CBJ set the minimum legal reserve requirement to $5 \%$ of total private and interbank deposits and borrowed in local currency.

To control and regulate credit, the $\mathrm{CBJ}$ imposed a $15 \%$ required reserve ratio on all deposits of foreign exchange units of all banks. The CBJ also determined the commissions that licensed banks can charge on transactions of documentary credits, transfers, bills and guarantees. Furthermore, the interest rates on cash margins of documentary credits were fixed at $2 \%$ below current interest rates on similar time deposits. Further, all banks were authorized by the CB to extend credit facilities, in local currency, to resident clients against their foreign currency deposits without prior approval of the $\mathrm{CBJ}^{(2)}$. Also, banks were authorized to grant JD credit facilities to their non-resident clients against foreign currency deposits inside Jordan without prior approval of the $\mathrm{CBJ}^{(3)}$. Due to the increased level of foreign reserves, the minimum cash margins collected by banks against documentary credits and sight drafts or guaranteed time drafts was lowered by the $\mathrm{CBJ}^{(4)}$.

By mid 1992, all banks were instructed to restrict their maximum credit facilities in local currency extended to non-residents to $5 \%$ of their total credit facilities. ${ }^{5}$ The CBJ raised interest and commissions rates charged by banks from exporters to $2 \%$ instead of $1.5 \%$. The aim was to encourage banks to provide such credit and promote it among customers. In order to activate the money market and to attract foreign capital, the CBJ authorized, by the year 1993, all banks to operate investment portfolios in foreign currencies for non-residents out of their accounts in foreign currencies as financed by transfers from abroad. During the same year, the CBJ issued certificate of deposits in U.S. currency for investment by the banks in a minimum amount of US $\$ 100,000$ and its multiplies. In addition, the banks were authorized to issue CDs in local currency and foreign exchange currencies for term not less than one month.

By the mid 1994, the CBJ lowered the Required Reserve Ratio (RRR) to become $14 \%$. But, to activate and promote the interbank market, the interbank, headquarters and foreign branch deposits in the local and foreign currency deposits were excluded from the base subject to the RRR in Local currency. By the same period, non-residents were permitted unconditional withdrawals and transfers from their accounts in foreign currencies maintained with licensed banks. During the early second half of the 1990s, 1995 in particular, the CBJ decided to raise the minimum paid-up capital for all banks to JD 20 million. Non- Jordanian licensed banks were asked to raise their capital to JD 10 million by the beginning of 1997 . In order to control risks arising from credit exposures to a single customer, a group related customers, or employees, the CBJ

(2) Each transaction should not exceed JD 100,000

(3) In this regard, the outstanding balance of credit facilities should not exceed the balance of foreign currency deposit.

(4) For more information regarding the instruction covering this issue, and the other amendments of the foreign exchange control regulations, see the CBJ 1991 Annual Report.

(5) These regulations required that the balance of foreign currency deposits of non-residents, which blocked in collateral, should not be less than the outstanding balance of credit facilities. 
determined the ceilings (maximums) of credit provided for each level. To activate the foreign exchange market and to further ease up foreign exchange control restrictions, banks were allowed by the CBJ to invest a maximum of $50 \%$ of their deposits in convertible foreign currencies.

By the year 1996, the CBJ decided to decrease the RRR on foreign deposits at banks from $35 \%$ to $14 \%$, and without interest. The motivation behind such action was to unify the reserve ratio in both domestic and foreign currency deposits, in addition to giving banks more freedom to manage their foreign currency assets as they fit. Taking into consideration also that banks were permitted to borrow locally in foreign currencies and invest internationally in investment portfolios for both resident and non-resident clients. As of the beginning of 1996, the CBJ raised the capital adequacy ratio from $8 \%$ to $10 \%$. Such action was undertaken to support the financial position of licensed banks as well as to improve their competitiveness and, thereby, enabling them to execute their role efficiently. In order to control risks arising from off-balance sheet exposure, the CBJ advised a conversion factor for each category on indirect credit facilities in order to calculate credit exposure for clients in accordance with the level of risk of each category.

Enhancing the soundness of the banking system and activating the interbank market was one of the main interests of the CBJ in the year 1997. In this regard, the CBJ raised the minimum capital adequacy ratio from 10\% to 12\% effective June 1997 financial statements. Further, the CBJ permitted trading of certificates of deposit in the interbank secondary market. By the year 1998, the CBJ focused on addressing the sharp demand for foreign currencies, and developing the money market (interbank market). During the period 1998 to 2001, the CBJ adopted a number of measures and legislative reforms. In the field of banking legislation, during 1998, the CBJ finalized a new draft Banking Law and a draft law for the establishment of a deposit insurance corporation. In preparing the two new draft laws, the CBJ took care to keep abreast with the new developments prevailing on the international banking arena.

The CBJ undertook several measures to control risks arising from credit exposures, to build provisions against non performing loans, and to adopt international accounting standards and disclosure. Further, the CBJ adopted the internationallyapproved comprehensive method of assessment of banks position i.e., banks businesses, capital, assets, management, profitability and liquidity. In accordance with international standards of banking supervision, the CBJ followed a gradual reduction of the rating period of non-performing loans and suspended interest thereon. In addition, to contain and follow up the problem of uncleared cheques, the CBJ established a special unit located in the Central Bank for such cheques. While observing international prudential standards, and in order to improve the ability of banks to manage their assets in foreign currencies, the CBJ followed a reduction policy for several restrictions on banks' foreign asset management. A new Banking Law and a Deposit Corporation Law were passed in 2000. Early 2001, the CBJ reduced the legal reserve requirement ratio on deposits in local currency and foreign currencies from $10 \%$ to $8 \%$.

\section{The Estimation Specification}

By using the standard profit function approach, as employed earlier by Hardy and Bonaccorsi (2001) and Berger and Humphrey (1997), this paper estimates the impact of the Jordanian regulatory reforms on the banking industry by estimating the effects on 
banks' cost efficiency, revenue efficiency and profitability. This has been accomplished by examining the banks' cost, revenue and profitability efficiencies as a function of relevant exogenous variables, including input and output prices. The standard profit function can be written in logarithmic form as: ${ }^{(6)}$

$$
\operatorname{In}\left(\pi_{i t}+\phi\right)=f_{\pi}\left(\mathrm{E}_{i}, \mathrm{H}_{t}, \mathrm{M}_{i t}, \mathrm{~K}_{t}\right)+\operatorname{In} \Gamma_{\pi i}+\operatorname{In} \varepsilon_{\pi i}
$$

Where $\pi_{i t}$ : Profits variable of bank $i$ at time $t . \phi$ : Constant added to insure the positive relationship. $f_{\pi}$ : Typified the profit optimizing behavior for bank $i$ at time $t$. $\mathrm{E}_{i}$ : A vector of input prices. $\mathrm{H}_{t}: \mathrm{A}$ vector of variable input prices. $\mathrm{M}_{i t}: \mathrm{A}$ vector of semi-fixed netputs. $\mathrm{K}_{t}$ : Environmental and structural variables. $\Gamma_{\pi i}$ : A fixed effect that represents the reduction in bank $i$ 's profits due to persistence of overall efficiency and assumed to be constant across the estimation period. $\varepsilon_{\pi i t}$ : Random error

By assuming a competitive market, all banks are price takers, and output prices can be measured. Hence, equation (1) can be re-written by substituting the bank output prices $\left(\Psi_{i t}\right)$ instead of the bank input prices $\left(\mathrm{E}_{i}\right)$. Specifically:

$$
\operatorname{In}\left(\pi_{i t}+\phi\right)=f_{\pi}\left(\Psi_{i t}, \mathrm{H}_{t}, \mathrm{M}_{i t}, \mathrm{~K}_{t}\right)+\operatorname{In} \Gamma_{\pi b}+\operatorname{In} \varepsilon_{\pi i t}
$$

Taking the fact that the reform regime has an impact on banks' profits, it has an impact on the banks' costs and revenues as well. Hence, the cost function can be written as:

$$
\operatorname{In}\left(C_{i t}\right)=f_{C}\left(\Psi_{i t}, \mathrm{H}_{t}, \mathrm{M}_{i t}, \mathrm{~K}_{t}\right)+\operatorname{In} \Gamma_{C b}+\operatorname{In} \varepsilon_{C i t}
$$

Similarly, the revenue function can be written as:

$$
\operatorname{In}\left(R_{i t}\right)=f_{R}\left(\Psi_{i t}, \mathrm{H}_{t}, \mathrm{M}_{i t}, \mathrm{~K}_{t}\right)+\operatorname{In} \Gamma_{R b}+\operatorname{In} \varepsilon_{R i t}
$$

\subsection{Data and Proxies of Variables}

The data related to the study sample was obtained from the banks' financial statements, in addition to the CBJ's monthly Bulletins ${ }^{(7)}$. The period of study encompasses 13 financial years, 1990-2002 inclusive. The particular technique that is used is to specify the interrelationship between profits, costs and revenues with input and output prices. Thus, based on equations 1 to 4, revenues (REV) are defined as the ratio of total operating and non-operating income divided by total assets. Costs (COS) are measured by summing total interest and non-interest costs divided by total assets. Profits (PRO) are measured by the difference between total revenues and total costs divided by total assets ${ }^{(8)}$.

(6) For more information regarding the econometric estimation for both profit and cost functions see Hardy and Bonaccorsi (2001) and Berger and Humphrey (1997).

(7) The study sample include Arab Bank (AR), The Housing Bank (TH), Jordan National Bank (JO), Jordan Islamic Bank for Finance and Investment (JI), Cairo Amman Bank (CA), Bank of Jordan (BO), Jordan Kuwait Bank (JK), Jordan Investment and Finance Bank (JM), Arab Jordan Investment Bank (AJ), Arab Banking Corporation-Jordan (AB), Union Bank for Saving and Investment (UB), Middle East Investment Bank (ME), Philadelphia Investment Bank (PH).

(8) For normalization purposes, all specific bank variables are divided by total assets. 
To measure the bank input and output prices, prior research studies adopt either the intermediation or production method. Under the production method, a financial firm is defined as a producer of services for account holders. That is, the financial firm performs deposit and loans transactions. Based on this method, the number of accounts might be relevant to be used as a proxy or indicator for output, while the number of employees and paid up capital can be used as proxy for inputs. Under the intermediation method, financial firms convert and transfer financial services between borrowers and lenders (surplus and deficit units). For this method, the output is defined as the dollar value of loans and deposits, while inputs include labor, fixed assets, and loanable funds ${ }^{(9)}$. For this study purposes, given the fact that interest expense often account and contribute largely (50\% or more) of total costs, the intermediation methods has been used ${ }^{(10)}$.

In this study, the bank's output (denoted as OUP) is measured by the bank average total interest earning assets-that comprise securities (including government securities, trading securities and investment securities) and credit facilities-relative to total assets. The unit price of the bank's output (OUC) is measured by total interest and non-interest income divided by the bank total average interest earning assets. The unit price of borrowed funds (BRF) is proxied by total expenses (including interest and non-interest expenses known as other expenses i.e., administrative and general expenses) divided by payable liabilities (due to other banks and deposits excluding capital).

The non interest unit costs (NIC), known as other costs, are measured by total non-interest expenses (including administrative and other general costs) divided by payable liabilities that include due to other banks and deposits for all interest bearing liabilities. Facility costs per unit of property (FCP) are measured by total fixed assets to total assets, and expected to vary between banks due to variation in quantity. While all banks are assumed to be price takers, the unit prices for input and output are assumed to be the same for all banks. The study uses the market power (denoted as MAP) as a relevant proxy in order to capture the environmental or structural factors. The market power is measured by the bank total deposits divided by the total deposits of all banks. The market power variable captures differences between banks in the degree of centralization, which tends to be high for banks with more branches and larger electronic network. Dummy variables were used to test the size impact.

\section{The Functional Estimation}

Table 1 presents the average time depiction of some efficiency variables used by the study, while Figure 1 portrays the trend of the revenues and profits efficiency variables during the study period that represents an era of deregulation. The figures show that both variables were fairly followed each other during the study period. There is no substantial increase in the banks' profits. The reason is attributed to the increase in both costs and revenues. The increase in the banks' average costs is attributed to the changes in the market conditions, in addition to the changes associated with the reforms of the whole financial sector which caused a structural change in the banks' costs.

(9) Sherman and Gold (1985), Ferrier and Lovell (1990), and Fried et al (1993) employed the production method, while Sathye (1999) used the intermediation approach.

(10) As reported by Sathye (1999) and Berger and Humphery (1997), the intermediation method has been found more relevant for financial firms as it is inclusive of interest expenses that often account for $50 \%$ or more of total costs. 
Table 1: Average Time Depiction of Efficiency Variables during the period of 1990-2001

$\begin{array}{cccccc}\text { Year } & \text { Bank output } & \begin{array}{c}\text { unit price of } \\ \text { bank output }\end{array} & \begin{array}{c}\text { unit price bowroed funds } \\ \text { (unit price of input) }\end{array} & \text { Other costs } & \begin{array}{c}\text { Structural } \\ \text { (environmental) factors }\end{array} \\ 1990 & 0.4675 & 0.0035 & 0.0503 & 0.0147 & 0.4533 \\ 1991 & 0.4194 & 0.0214 & 0.0407 & 0.0138 & 0.5394 \\ 1992 & 0.4055 & 0.0176 & 0.0377 & 0.0127 & 0.5366 \\ 1993 & 0.4298 & -0.0048 & 0.0442 & 0.0163 & 0.5373 \\ 1994 & 0.4793 & -0.0048 & 0.0442 & 0.0169 & 0.5171 \\ 1995 & 0.5098 & 0.0249 & 0.0522 & 0.0181 & 0.4782 \\ 1996 & 0.5251 & 0.0355 & 0.0596 & 0.0196 & 0.4991 \\ 1997 & 0.4995 & 0.0197 & 0.0595 & 0.0192 & 0.5403 \\ 1998 & 0.4928 & 0.0238 & 0.0583 & 0.0190 & 0.5268 \\ 1999 & 0.5131 & 0.0031 & 0.0545 & 0.0175 & 0.5580 \\ 2000 & 0.4653 & 0.0072 & 0.0508 & 0.0164 & 0.6038 \\ 2001 & 0.4892 & 0.0052 & 0.0527 & 0.0170 & 0.5809\end{array}$

Figure 1: Average Revenues and Profits (Average Percentage Terms Relative to Total Assets)

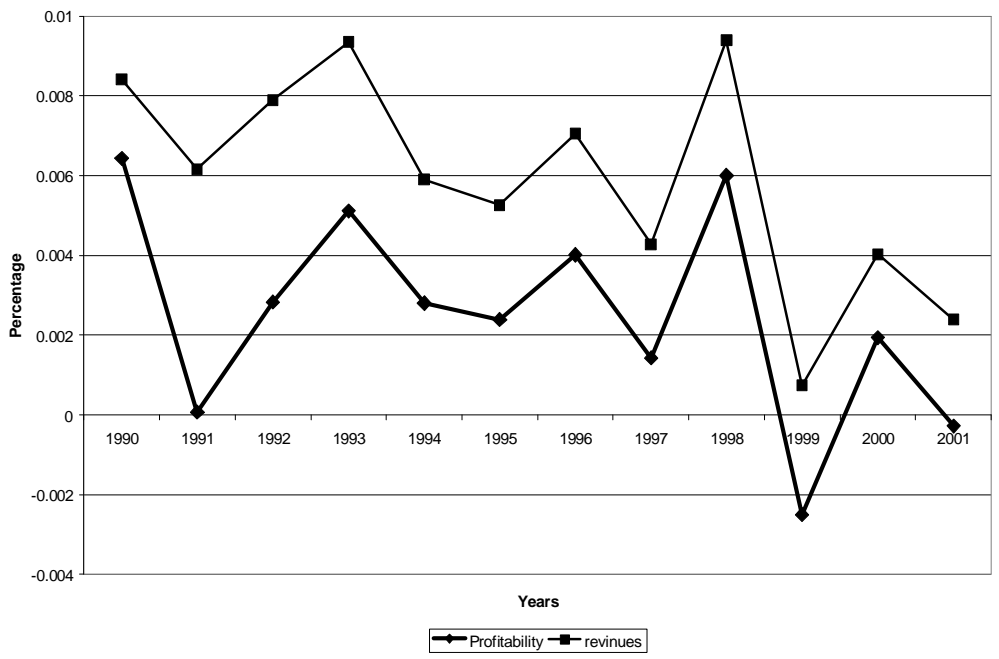


Furthermore, it seems that the increased competition created by the new reform and control measures forced most banks to follow a restricted behavioral policy of not widening their spreads, and focusing mainly on achieving stable interest margins. The depiction shows that profits reached their minimum level by the years 1991 and 1999 . The sharp decrease in profits in 1991 might be attributed to the tight instructions regarding the commissions that licensed banks can charge on transactions of documentary credits, transfer, bills and quarantines. An additional reason might be the new control measures provided by the CBJ to fix interest rates on cash margins of documentary credits at $2 \%$ below current interest rates on similar time deposits. By following Figure 1 it could be argued that financial reforms have led to a sharp increase in both revenues and costs for banks. This implies that competition encouraged by reforms provide the incentive to banks to increase their dependence on the interbank funding, in addition to increasing their access to the deposits market, including the household and enterprises, as the main source of funds to all banks. This indicates also less reliance on using both capital and reserves as an alternative to deposits and interbank borrowings to finance operating businesses.

In line with the downward trend in 1999, the interest rate on 3-month CDs dropped from $9.45 \%$ at the end of 1998 to $6 \%$ at the end of 1999 , and on 6-months CDs from $9.55 \%$ to $8.25 \%$. To face the reduction in profits in the year 1999 , the CBJ took several measures to influence the gradual reductions in the interest rate charged by banks with the aim of stimulating and activating economic growth. Of these measures are reducing the discount rate from $9 \%$ at the end of 1998 to $8 \%$ at the end of 1999 . Reducing one-week CDs repurchase agreements rate from $11.5 \%$ at the end of 1998 to $9.25 \%$ at the end of 1999 , and reducing the overnight deposit window rate from $8.5 \%$ at the end of 1998 to $0.50 \%$ at the end of 1999 , on aggregate bases.

Figure 2 shows the evolution over time of the bank output (OUP), the average unit price of bank output (OUC), and the average unit price of borrowed funds (BRF). Both of the average unit price of output (OUC) and the average unit cost of funds (BRF) seem fairly stable at around $8 \%$ and $3 \%$ respectively. Both showed a slight increase in 1994 and a slight decrease after 1996. All indicates a roughly constant spread. The trend pattern of bank output, unit price of bank output, unit price borrowed funds and other costs is presented throughout Figure (3). 
Figure 2: Banks' Output, Unit Price of Output, and Unit Price of Borrowed Funds (Average Percentage Terms)

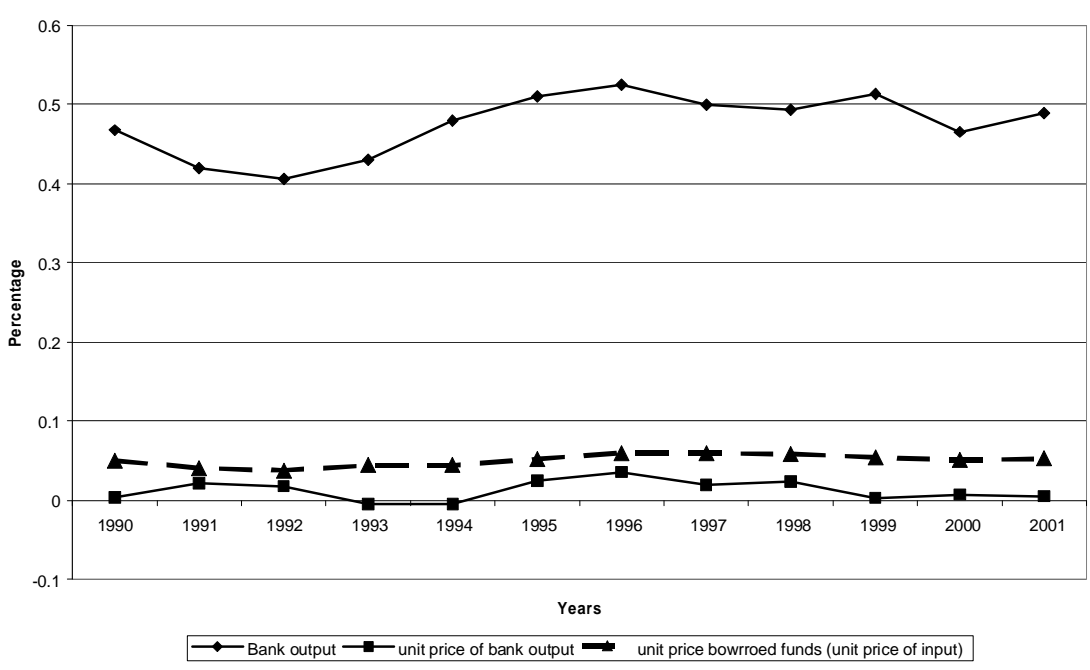

Figure 3: Bank Output, Unit Prices and Costs (Average Percentage Terms)

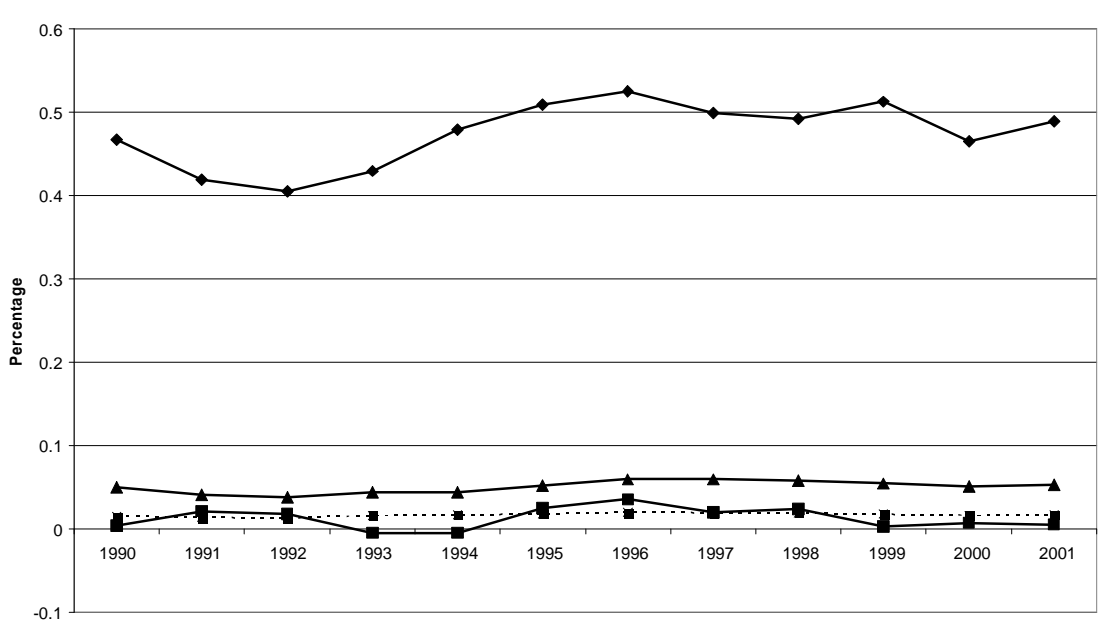

Years

$\longrightarrow$ Bank output $\longrightarrow$ unit price of bank output $\longrightarrow$ unit price bowrroed funds (unit price of input) $\cdots \cdots$ Other costs 
In accordance with the regression estimation, for the full sample, the standard profit function to be used is assumed to take the form of equation (5), while, the final estimated equations for the revenue and cost functions took the form presented in equations (6) and (7) below $^{(11)}$.

$$
\begin{gathered}
\operatorname{In}\left(\pi_{i t}+\phi\right)=\mathrm{B}_{\mathrm{o}}+\mathrm{B}_{1} \operatorname{InOUC}+\mathrm{B}_{2} \operatorname{InBRF}+\mathrm{B}_{3} \operatorname{InNIC}+\mathrm{B}_{4} \operatorname{InFCP}+\mathrm{B}_{5} \operatorname{InMAP}+\mathrm{U}_{\mathrm{it}} \ldots(5) \\
\operatorname{In}\left(C_{i t}\right)=\mathrm{B}_{\mathrm{o}}+\mathrm{B}_{1} \operatorname{InOUP}+\mathrm{B}_{2} \operatorname{InBRF}+\mathrm{B}_{3} \operatorname{InNIC}+\mathrm{B}_{4} \operatorname{InFCP}+\mathrm{B}_{5} \operatorname{InMAP}+\mathrm{U}_{\mathrm{it}} \ldots \ldots \ldots(6) \\
I n\left(R_{i t}\right)=\mathrm{B}_{\mathrm{o}}+\mathrm{B}_{1} \operatorname{InOUP}+\mathrm{B}_{2} \operatorname{InBRF}+\mathrm{B}_{3} \operatorname{InNIC}+\mathrm{B}_{4} \operatorname{InFCP}+\mathrm{B}_{5} \operatorname{InMAP}+\mathrm{U}_{\mathrm{it}} \ldots \ldots .(7)
\end{gathered}
$$

Tables (2) to (4) below present a functional panel data estimation for the efficiency measures under consideration (revenues, costs and profits functions). Under the study

Table (2): Pooled Least Squares Estimates of Revenues,

\begin{tabular}{|c|c|c|c|c|}
\hline \multirow{2}{*}{$\begin{array}{l}\text { Coefficients estimates } \\
\text { Intercept }\end{array}$} & \multicolumn{3}{|c|}{ Method of Estimation } & REM \\
\hline & \multicolumn{3}{|c|}{$\begin{array}{l}0.0244 \\
(3.0435) * *\end{array}$} & 0.0304 \\
\hline OUC & \multicolumn{2}{|c|}{$\begin{array}{l}0.0742 \\
(3.3997) * *\end{array}$} & 0.0719 & $\begin{array}{l}0.0707 \\
(46229) * *\end{array}$ \\
\hline $\mathrm{BRF}$ & \multicolumn{2}{|c|}{$\begin{array}{l}-0.1263 \\
(-19129) *\end{array}$} & $\begin{array}{l}-0.2856 \\
(-2.1980) *\end{array}$ & $\begin{array}{l}(4.0229)^{2} \\
-0.2085 \\
(-2.1288) *\end{array}$ \\
\hline NIC & \multicolumn{2}{|c|}{$\begin{array}{l}-0.4435 \\
(-2.4845) * *\end{array}$} & $\begin{array}{l}-0.7265 \\
(-2.0831)^{*}\end{array}$ & $\begin{array}{l}-0.5495 \\
(-1.8664) *\end{array}$ \\
\hline FCP & \multicolumn{2}{|c|}{$\begin{array}{l}0.0532 \\
(3.0826) * *\end{array}$} & $\begin{array}{l}0.0973 \\
(3.8440) * *\end{array}$ & 0.0804 \\
\hline \multirow[t]{14}{*}{ MAP } & \multicolumn{2}{|c|}{$\begin{array}{l}-0.0271 \\
(-2.2988) *\end{array}$} & $\begin{array}{l}-0.0406 \\
(-3.3099) * *\end{array}$ & $\begin{array}{l}-0.0325 \\
(-3.2027) * *\end{array}$ \\
\hline & \multicolumn{3}{|c|}{ Fixed Effects } & Random Effects \\
\hline & & AR & 0.0352 & -0.0033 \\
\hline & & TH & 0.0419 & 0.0019 \\
\hline & & JI & 0.0234 & -0.0092 \\
\hline & & CA & 0.0507 & 0.0072 \\
\hline & & $\mathrm{BO}$ & 0.0467 & 0.0038 \\
\hline & & JK & 0.0467 & 0.0047 \\
\hline & & JM & 0.0369 & -.0007 \\
\hline & & AJ & 0.0389 & 0.0003 \\
\hline & & $\mathrm{AB}$ & 0.0396 & -0.0004 \\
\hline & & UB & 0.0401 & 0.0002 \\
\hline & & $\mathrm{ME}$ & 0.0395 & -0.0026 \\
\hline \multirow{2}{*}{\multicolumn{2}{|c|}{ Coefficients of Determination $\mathrm{R}^{2}$}} & $\mathrm{PH}$ & 0.0336 & -0.0059 \\
\hline & & 0.3764 & 0.5789 & 0.5594 \\
\hline \multicolumn{2}{|l|}{$\begin{array}{l}\text { Adjusted } \mathrm{R}^{2} \\
\text { Standard error }\end{array}$} & 0.3446 & 0.4957 & 0.5369 \\
\hline \multicolumn{2}{|l|}{$\begin{array}{l}\text { Standard error } \\
\text { of the Estimate (SEE) }\end{array}$} & & 然 & \multirow{3}{*}{0.0083} \\
\hline \multicolumn{2}{|l|}{$\begin{array}{l}\text { of the Estimate (SEE) } \\
\text { F-statistic }\end{array}$} & 11.8304 & $* * 29.5609 *$ & \\
\hline Prob (F-statistic) & & 0.0000 & 0.0000 & \\
\hline
\end{tabular}
Costs and Profits Given Input and Output Prices.

Function: PRO

(1) Asterisks (*) indicate significant at $5 \%$ level, while asterisks (**) indicate significant at $1 \%$ level.

(11) For equations (6) and (7), we replace the output price (OUC) by the bank's output (OUP) only, other things remain the same. 
Table (3): Pooled Least Squares Estimates of Revenues, Costs and Profits Given Input and Output Prices.

Function: COS

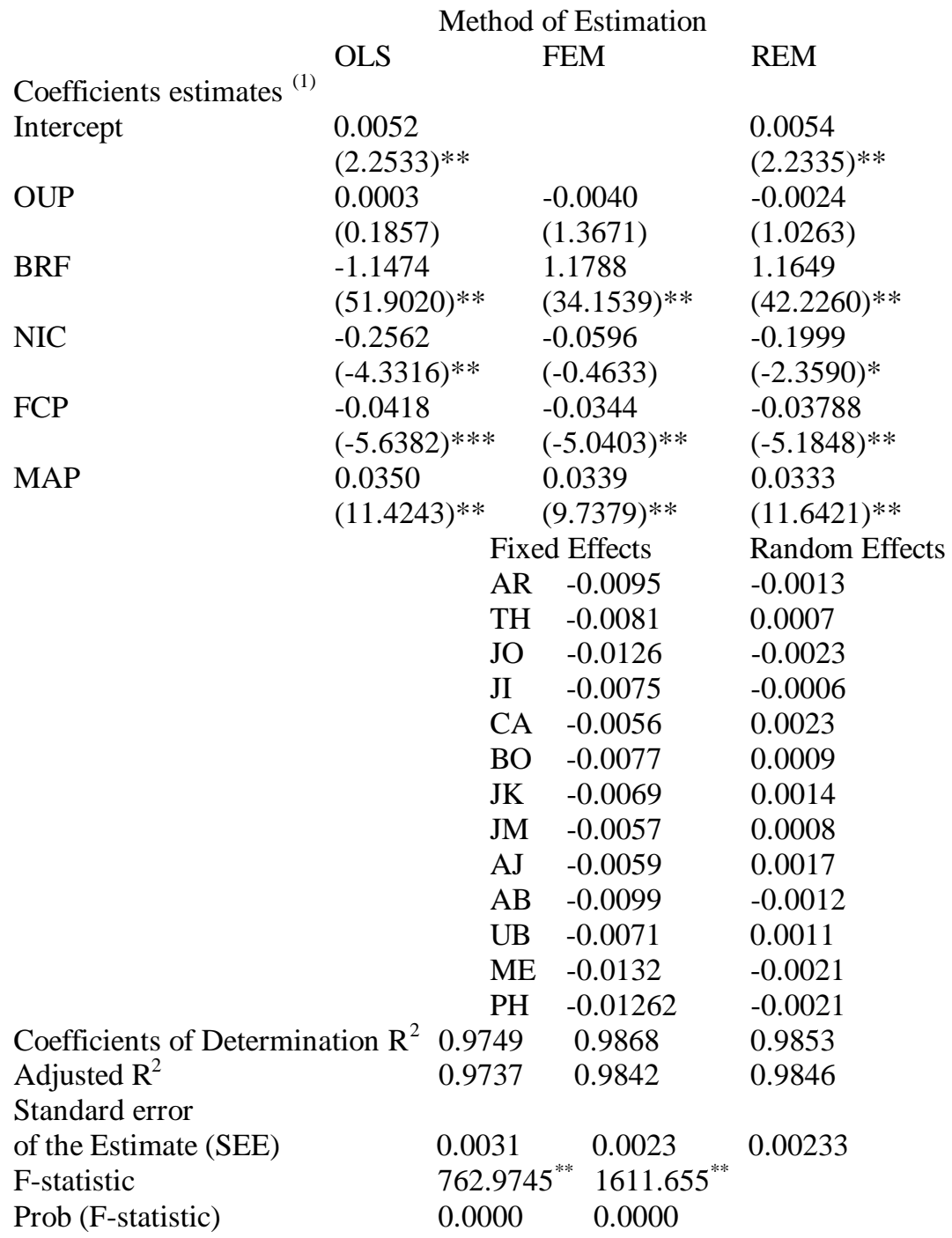

(1) Asterisks (*) indicate significant at $5 \%$ level, while asterisks (**) indicate significant at $1 \%$ level. 
Table (4): Pooled Least Squares Estimates of Revenues, Costs and Profits Given Input and Output Prices.

Function: REV

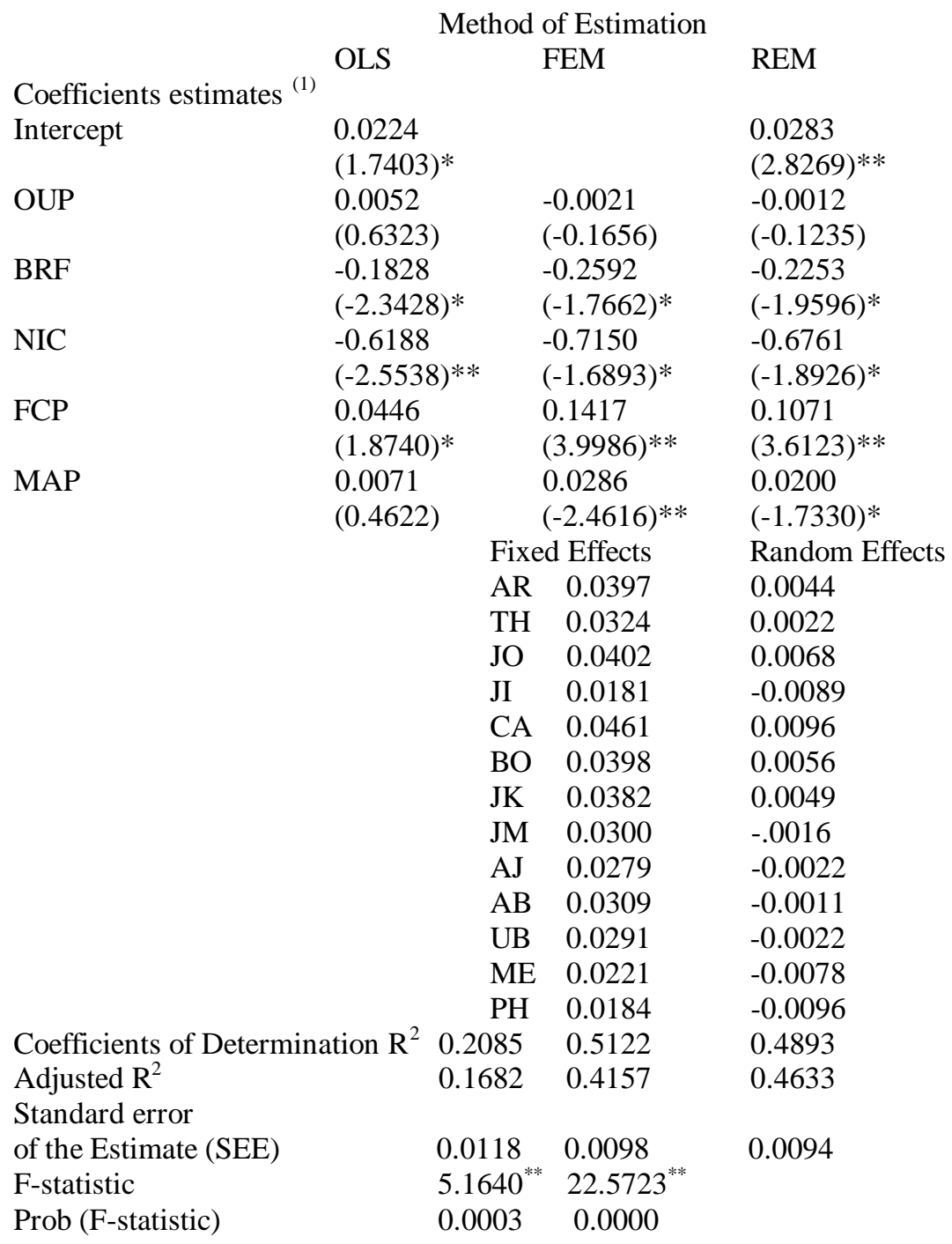

(1) Asterisks (*) indicate significant at 5\% level, while asterisks (**) indicate significant at $1 \%$ level.

concern, these measures form the basic measures of efficiency. All equations are estimated using a panel data from a sample over which banks performance is assumed to be stable. Both of the Fixed Effect Model (FEM) and Random Effect Models (REM) are used to obtain the estimated parameters. The results obtained by Ordinary Least Squares (OLS) are also reported for comparison purposes. The overall fit is satisfactory. Higher $\mathrm{R}^{2}$ statistics is achieved for the costs and profits functions compared to the 
revenue function. This implies that the fixed effects that indicated a relative efficiency are normally highly significant. These results are consistent under the REM.

As a notable observation, it seems that the estimated coefficients under the REM tend to be larger in absolute terms and more explanatory power is obtained. The estimation shows that there are relative differences between the estimated coefficients by using FEM and REM, under which higher coefficients for the profit and revenue functions and lower coefficients for the cost function are reached. These differences vary over time and across banks. While the reform instructions were constructed mainly and heavily after the mid-half of the 1990s, the estimated equations were re-run again in order to test for the sub-period differences (before and after 1997). The test reveals an indication that there were greater relative levels of inefficiency in generating revenues for the second period, after 1997. The test reveals also relative cost inefficiency for most banks. Under this behavior, it can be concluded that banks after the second reform subperiod have become more competitive, leading to less revenues size, and beard higher direct and indirect costs, reflecting lower spreads.

The structural error of the second sub-period estimation was much higher compared to the first-sub-period. This suggests that some banks in the sample were more powerful than other banks in adapting to the new reform conditions (terms or circumstances). Through comparing OLS, FEM and REM results, it appears that OLS measures of revenues, profit and costs tend to be lower in absolute terms. The standard error of the OLS coefficients is greater as well. Based on OLS measures, there are improvements in revenues, profits and costs efficiencies during the whole reform and deregulation periods, in which coefficients were getting larger. This indicates that the relative revenue and then profit efficiency have been improved due to substantial improvement in cost efficiency for most banks.

On sub-sample basis, compared to non-major banks, the estimation indicated that the major banks (those with higher total average interest earning assets) have achieved higher profit levels, reflecting more relative efficiency in terms of revenues and costs performance during the 1990s. This could be due to economics of scale and scope, in addition to differences in the level of output, capitalization and reliance on deposits (the free fund deposits in particular). Furthermore, the result indicates that reform provided the chance and incentive for the major banks to increase their costs and revenues efficiencies and subsequently maximize their relative profits. The non-major banks relative inefficient profitability can be attributed to revenues and costs relative inefficiencies. The differences in revenues and costs efficiencies between major and non-major banks reflect the differences between the two categories in specialization. But, over time, it appears that the full sample relative revenue and then profit efficiency are stable.

The improvements in banks' revenues, costs and profits, in addition to the general stability of the banking sector, suggested that the banking controls adopted by the CBJ during the late 1998s and early 1990s have improved the soundness of the banking sector in Jordan. This is clear while the CB enhanced its supervision and reached an adequate level of prudential control. Through this the CB took care toward long-term or risky sectoral businesses. Further, the CB enhanced its surveillance role by forcing banks to have relevant credit risk analysis, expand and diversify their loan portfolio allocation, in addition to identify the non-performing loans and develop proper loan loss provisions. 
In this regard, the $\mathrm{CB}$ new reform forced banks to (1) undertake several measures to control risk arising from credit exposure; (2) build proper provisions against nonperforming loans; (3) adopt international accounting standards and disclosure; (4) adopt the internationally-approved comprehensive method of assessment of banks position, particularly banks capital and liquidity. Further, in accordance with international standards of banking supervision, the CBJ followed a gradual reduction of the rating period of non-performing loans and suspended interest thereon. In addition, the CBJ decrease overexposure level of the banking businesses toward the real estate market, decrease level of speculation on the foreign exchange, and controlled the overexposed size of foreign obligations.

More precisely, in the early 1990s, with respect to interest rate, the CBJ raised interest on direct credit facilities extended to residents by licensed banks from $9 \%$ to $10 \%$, and $10 \%$ on credit extended to specialized credit firms, while interest charged to non-residents was propped up to $13 \%$. On the other hand, the CBJ raised its discount rate to $8.5 \%$. Further, banks were allowed to extend their direct credit in excess of JD 200,000 with prior approval of the CBJ. The enhancement in revenues is also attributed to the liberalization of the interest rates charged by banks on different types of banks ' facilities, and lowering the required reserve ratio on both local and foreign currencies. Furthermore, the CBJ authorized banks to extend credit facilities in local currency to resident clients against their foreign currency deposits. The $\mathrm{CBJ}$ also raised interest and commissions rates charged by banks from exporters to be $2 \%$ instead of $1.5 \%$. Banks were allowed to operate investment portfolios in foreign currencies for non-residents out of their accounts in foreign currencies as financed by transfers from abroad. Also, banks increased their investment in CD's in U.S Dollars issued by the CB in a minimum of $\$ 100,000$ and its multiples.

The positive and significant impact of OUP, OUC, and FCP variables on banks' revenues and profits is attributed to some factors. First, the liberalization of the interest rates charged by banks on the different types of banking facilities. Second, the increased level toward local investments, particularly investing in local shares that were increased to $20 \%$ of total paid up capital and reserves. Third, the significant improvements in the financial exchange position of the financial system. This factor is supported by several procedures including the modifications adopted toward foreign exchange control instructions, particularly increasing the ceiling of foreign currency deposits held by residents, in addition to limiting foreign currency deposits held by exporters with local banks to only $10 \%$ instead of $30 \%$. Fourth, the increase in interest rates and the commission rates charged by banks from exporters, in addition to the expansion of issuing CDs in both local and foreign currencies. The low explanation power of OUC could be justified due to the tight instructions regarding the ability of banks to generate non-interest income typified by the commissions that banks can charge on transactions of documentary credits, transfer, bills and quarantines. An additional justification is the new instructions provided by the CBJ to fix interest rates on cash margins of documentary credits at $2 \%$ below current interest rates on similar time deposits.

The variables BRF and NIC have significant relationship with revenues and profits. This is attributed to the active promotion toward the interbank market, which is excluded from the base subject to the RRR, in addition to increasing the minimum capital adequacy ratio. Further, permitting trading of CDs in the interbank secondary 
market served as a helpful factor. The low explanation power of these variables is attributed to the more reliance of banks in using capital and reserves as alternatives to deposits and interbank deposits to finance their operating businesses.

The market power proxy (MAP) is significant in its relationship with profits. The result indicates that a greater market share obtained by banks causes increased market power leading to an increase in bank profitability. Actually, while testing the impact of the market power proxy, there was evidence that Jordanian banks responded to the competitive forces. The result implies that higher market power allows banks to extract higher spreads, leading to a positive impact on their profitability.

The result provides an indication that during the post-deregulation period, after 1997 in particular, Jordanian banks have significantly expanded their market share and their profitability levels, causing an improvement in their interest rate spreads. As a result, the increase in the banking market share gained by banks allows for more market power, enabling banks to increase their margins by increasing loan rates or reducing deposit rates depending on the competitive environment in the banking market. The negative sign indicates that, particularly in the early stages of the post reform regime that represents the second half of 1990s, the competitive pressure in banking business forced banks to compete again by squeezing their spreads and margins, reflecting more elastic demand and supply functions, in the face of which banks are not be able to exercise monopoly power.

The result takes into account the view of McShane and Sharpe (1985) that attempting to increase market power in the short run can cause a reduction in the bank's net interest income and then its net interest rate margin. But, in general, the existence of regulatory and political considerations can constrain the bank's capacity to fully exploit increased market share, which in turn impacts its market power, causing lower spreads and then lower margins. Even though, in the long run specifically, increased market share will cause greater market power, leading to a widening spread and then profitability.

Regarding the enhancement in costs, it seems that most banks benefited from lowering the rate of the required reserve ratio during the 1990s charged on both local and foreign deposits. But, given the improvement in both revenues and costs, still banks faced a narrow net profit levels. This might be due to tight instructions imposed on noninterest income generated by banks, of which, the CBJ limited the commissions that might be charged by banks on transactions of documentary credits, transfers, bills and guarantees. Further, the CBJ restricted the maximum credit facilities in local currency extended to non-residents to 5\% of the banks' total credit facilities. In addition, the CBJ implemented several techniques in order to enhance the competitiveness environment in the banking industry, of which, the CBJ authorized banks to decide by themselves the percentage of cash margins that they charge their clients in cases of imports to Jordan.

By the year 2000, banking commissions and fees were deregulated, and banks were entitled to set their own rates. Banks were required to announce their prime lending rates and any adjustment. Banks were given access to inquire electronically about uncleared cheques, in addition to the ability of electronic inquiry for client's credit risk. An additional factor is the $\mathrm{CB}$ requirement of increasing the capital adequacy from $8 \%$ to $10 \%$ then to $12 \%$ by the year 1997 . This action, in addition, it supported the financial position of banks, it increased the level of competitiveness and 
hence enabling banks to execute their role efficiency. The CBJ followed measures to urge banks to develop and increase the capital efficiency by introducing client portfolio managed in local currency

The effect of the structural factor seems highly significant. This implies that the banks' overall performance has improved during the reform period. This could be justified and attributed to the relevant response of banks to the reform enhancement by adopting structural changes in the banking industry, such as technological developments, the opening of new funding and investing markets (techniques), and the change in the market conditions such as interest rates. All these factors have a valuable impact on profitability, cost and revenues on banks performance. There are differences among banks. On the degree of improvement under which some banks achieved lower degree of improvements. This might be justified due to the changes in the market condition and the ability of each particular bank to cope with the changing conditions.

Further, the structural factors create substantial changes in the revenue part. Under the new banking reform, banks started to seek and offer better banking services in more competitive environment, in addition to new open up market segments. All cause unit costs and unit revenues to be higher. This result is supported by Grabowski et al (1994), Naughton and Harvie (1996) for Australian banks, Berger and Master (1997) for U.S banks, Lozano (1998) for Spanish banks, and Hardly and Bonaccorsi (2001) for banks in Pakistan.

\section{Conclusions and Implications}

This paper has attempted to assess whether bank deregulation and reform regimes undertaken by the CBJ led to an improvement in the performance efficiency of banks, and whether the regimes created structural changes in the banks' investing and financing behavior. The main conclusions are summarized as follows.

First, Most of the regulatory reforms and structural changes, particularly those undertaken during the crises period, had a significant impact on the Jordanian banking behavior. Most measurement controls adopted during the 1980s' and 1990s' provided the chance for more competition, which had greater incentive for banks to lower holding of excess liquid assets and thus improve profitability and cost efficiency. Therefore, banks began to expand their banking operation toward non-traditional banking businesses, and granting a greater scope of business, in addition to providing more focus on the local market. Thus, the increased competition forced banks to focus on increasing their revenues by expanding their market share, and cutting down their cost levels. Under this conclusion, it is assumed that the new banking behavior is reflected positively through improving revenues ands costs efficiencies of banks.

Second, throughout the analysis, it could be concluded that most of the improvements in the banking industry were attributable to market conditions such as interest rates, in addition to the structural factors such as the advanced technology and competitive behavior. These conditions transformed the banking industry to become more open and more competitive causing an overall enhancement in the macroeconomic performance. In Jordan, it seems that the movement toward deregulation provided modern prudential regulation and supervision. It created tremendous changes toward the scope of competition, allocation of resources, less market concentration, and the introduction of new financial products and banking services as well. 
Third, the analysis reveals that there were improvements in both revenues and costs. This implies that the benefit from reform was passed to clients of the bank including public and private borrowers, clients of transactions services, and banks suppliers of funds, particularly depositors. While the reform allowed banks to improve their underlying revenues and costs performance, it is very obvious that reform did not cause a substantial increase in profitability. This is because of the increased level of competition, in addition to the increase in deposit interest cost of funds.

Fourth, the significant impact of the borrowed fund variable reveals an active and promotes interbank market. This is clear where the CBJ excluded interbank, headquarters and foreign branch deposits in local currency from the required reserve ratio in the local currency.

Fifth, the differences between major and non-major banks in achieving different levels of performance efficiency over the sample period is attributed to the fact that major banks are more capitalized, less leveraged and more provisioned. This suggests that the balance sheets for major banks are more structurally sound than those of nonmajor banks. The result reflects also that tighter credit review standards adopted by the major banks compared to non-major banks. This leads to a conclusion that a further entry of new banks, provided that they are well capitalized and more technologically advanced, is likely to improve the performance of the banking sector.

Sixth, in accordance with the structural impact, the study indicated a link between banks' efficiency performance and their subsequent market share. This implies that the market share strengthens significantly after deregulation as competitive reallocation affects transfer assets to better performance. This implies that when the market becomes more open, the link between performance and market share increases significantly. Over time, this competitive reallocation controls the banking industry toward better performance. It could be concluded that competition created due to deregulation has successfully transferred a substantial portion of banking assets from low profit to high profit banks and contributed to the increased profitability of the banking industry as a whole.

The overall outcomes suggest the need for the CBJ to undertake more comprehensive and drastic steps for restructuring the banks, particularly those with low and unstable levels of performance efficiency. In order to have more viable and modern commercial oriented banking sector, the results suggest further emphasis on the expansion of scope of businesses, and more entry deregulations for banking members that are well capitalized and technologically advanced. The study suggests also that the movement toward more deregulation should not tend to create more fragile financial firms, whose aggressive credit policy and assets liabilities mismatch might lead to face more risk exposure. 


\section{References}

Berger, A. and Humphrey, D. (1997). Efficiency of Financial Institutions: International Survey and Directions for Future Research. European Journal of Operational Research, Vol. 98, No. 2, pp.175-212.

Berger, A. and Master, L. (1997). Inside the Black Box: What Explains Differences in the Efficiency of Financial Institutions? Journal of Banking and Finance, Vol. 21, pp. 895-947.

Berger, A. Humphrey, D., and Lawrence, B. (1996). Do Consumers Pay for One-Stop Banking? Evidence from an Alternative Profit Function. Journal of Banking and Finance, Vol. 20, pp. 1601-1621.

Berger, A. (1993). Distribution-Free Estimates of Efficiency in the U.S. Banking Industry and Tests of the Standard Distributional Assumption. Journal of Productivity Analysis, Vol. 4, pp. 261-292.

Berger, A. Hancock, D., and Humphrey, D. (1993). Banking Efficiency Derived from the Profit Function. Journal of Banking and Finance, Vol. 17, April, pp.317-347.

Berger, A. Hunter, W., and Timmes, S. (1993). The Efficiency of Financial Institutions: A Review and Preview of Research Past, Present and Future. Journal of Banking and Finance, Vol. 17, pp. 221-249.

Bhattacharyya, A. Lovell, C., and Sahay, P. (1997). The Impact of Liberalization on the Productive Efficiency of Indian Commercial Banks. European Journal of Operational Research, Vol. 98, pp. 332-345.

Chauffour, J. (1996). Financial Liberalization and Monetary Reform. International Monetary Fund (IMF), Jordan Strategy Adjustments and Growth, Central Bank of Jordan, pp. 34-48.

Demetriades, P. and Kul, B. (1996). Financial Development Economic Growth and Banking Sector Controls: Evidence from India. The Economic Journal, Vol. 106, pp. 359-347.

Elyasyiani, E. and Mehdian, S. (1995). The Comparative Efficiency Performance of Small and Large US Commercial Banks in the Pre-and Post Deregulation Eras. Applied Economics, Vol. 27, pp. 1069-1079.

Ferrier, G. and Lovell, C. (1990). Measuring Cost Efficiency in Banking: Econometric and Linear Programming Evidence. Journal of Econometrics, Vol. 46, pp. 229-245.

Fried, H. Lovell, C., and Eackaut, P. (1993). Evaluating the Performance of US Credit Unions. Journal of Banking and Finance, Vol. 17, pp. 251-265.

Gilbert, R. and Wilson, P. (1998). Effects of Deregulation on the Productivity of Korean Banks. Journal of Economics and Businesses, Vol. 2, pp. 133-156.

Grabowski, R. Nada, R., and Rasoul, R. (1994). The Effects of Deregulation on the Efficiency of U.S. Banking Firms. Journal of Business and Economics, Vol. 46, pp. 39-54.

Hardy, D. and Bonaccorsi, E. (2001). Bank Reform and Bank Efficiency in Pakistan. IMF Working Paper 01/138, Washington: International Monetary Fund.

Humphrey, D. and Pulley, L. (1997). Banks' Responses to Deregulation: Profits, Technology, and Efficiency. Journal of Money, Credit and Banking, Vol. 29, No. 1, pp.73-93.

Hunter, W. and Timmes, S. (1993). Technical Change, Organizational Form and the Structure of Bank Production. Journal of Money, Credit and Banking, Vol. 18, No. 2, pp.152-166.

Jbili, A. Klaus, E., and Volker, T. (1997). Financial Sector Reforms in Algeria, Morocco, and Tunisia: A preliminary Assessment. IMF Working Paper 95/81, Washington: International Monetary Fund.

Johnston, R. and Ceyla, P. (1995). Linkage Between Financial Variables, Financial Sector Reform and Economic Growth and Efficiency. IMF Working Paper 95/103, Washington: International Monetary Fund.

Kumbhakar, S. Vivas, A. Lovell, C., and Hasan, I. (2001). The Effects of Deregulation on the Performance of Financial Institutions: The Case of Spanish Savings Banks. Working Paper Department of Economics, University of Texas at Austin, Texas, USA.

Lee, C. Lee, K., and Lee, K. (2000). Chaebol, Financial Liberalization, and Economic Crises: Transformation of Quasi-Internal Organization in Korea. East-West Center, Honolulu, Hawaii, Working Paper, No. 101, August. 
Lozano, V. (1998). Efficiency and Technical Change for Spanish Banks. Applied Financial Economics, Vol. 8, pp. 289-300.

Martinez, G. (2001). Bank Runs and Financial Liberalization: The Case of Ecuador. On lineAvailable at $h t t p: / / w w w . n d . e d u$

McShane, R. and Sharpe, I. (1985). A Time Series / Cross Section Analysis of the Determinants of Australian Trading Banks Loan/Deposit Interest Margins: 1962-1981. Journal of Banking and Finance, Vol. 9, (August), pp.115-136.

Naughton, T. and Harvie, C. (1996). The Performance of Foreign Banks in Deregulated Environment: Evidence from Australia and Korea. Economic Papers, Vol. 15, No. 1, pp. 57-75.

Nickell, S. (1996). Competition and Corporate Performance. Journal of Political Economy, Vol. 104, August, pp. 724-745.

Sathye, M. (1999). X-Efficiency in Australian Banking: An Empirical Investigation. Journal of Banking and Finance, Vol. 17, No. 5, pp. 1-19.

Sherman, D. and Gold, F. (1985). Branch Operating Efficiency: Evaluation with Data Envelopment Analysis. Journal of Banking and Finance, Vol. 9, pp. 297-315.

Shirai, S. and Rajasekaran, P. (2001). Assessment of China's Financial Reforms. Economic and Social Commission for Asia and the Pacific (ESCAP), Joint Workshop on Mobilizing Domestic Finance for Development: Reassessment of Bank Finance and Debt Markets in Asia and the Pacific, 22-23 November, Bangkok.

Stiroh, K. and Strahan, P. (2002). Competitive Dynamics of Deregulation: Evidence from U.S. Banking. Research Working Paper, Federal Reserve Bank of New York, New York, USA.

Vivas, L. (1998). Efficiency and Technical Change for Spanish Savings Banks. Applied Financial Economics, Vol. 8, pp. 289-300.

Vivas, L. (1997). Profit Efficiency for Spanish Savings Banks. European Journal of Operational Research, Vol. 98, No. 2, pp. 381-394. 


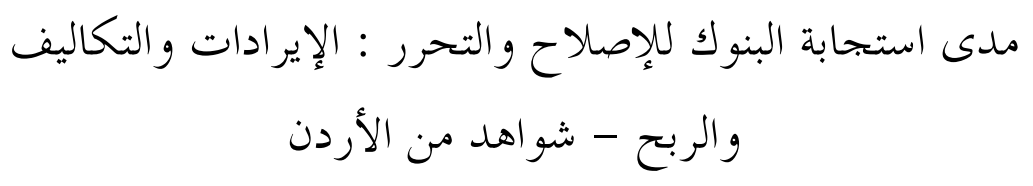

$$
\begin{aligned}
& \text { محمد العبادي و خالد الزوبي و حسني خريوش } \\
& \text { أساتنة مساعدون } \\
& \text { قسم العلوم المالية - كلية الاقتصاد والعلوم الإدارية } \\
& \text { الجامعة الهاشمية - الزرقا - الأردن }
\end{aligned}
$$

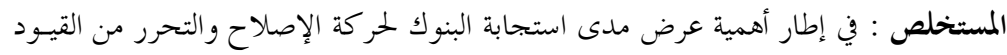

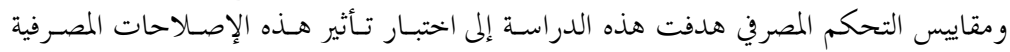

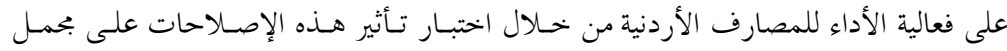

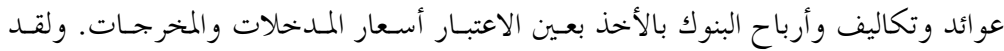

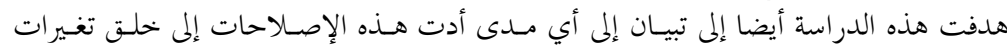

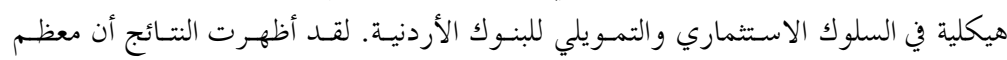

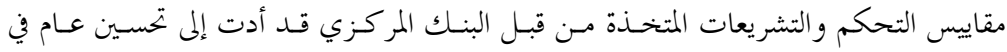

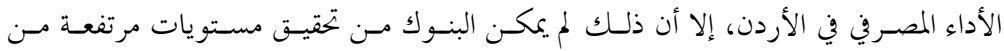

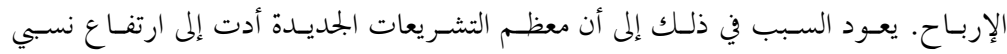

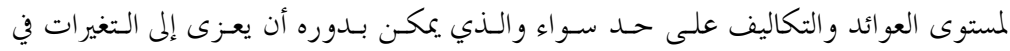

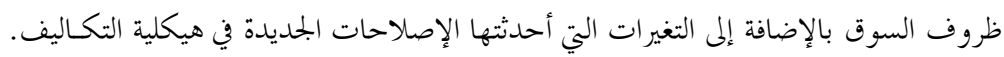

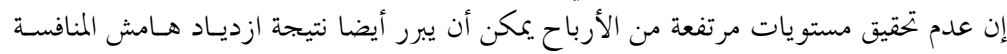

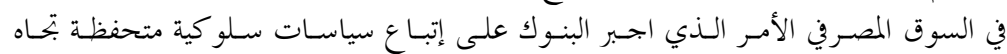

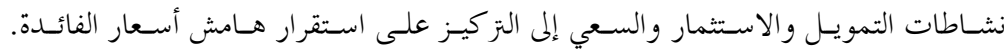

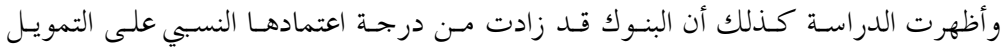

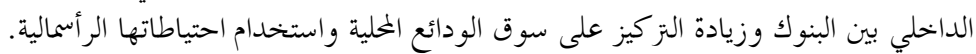

